\title{
UKREPI ZA ZMANJŠANJE TVEGANEGA IN ŠKODLJIVEGA PITJA ALKOHOLA V POPULACIJI ŠTUDENTOV: SISTEMATIČNI PREGLED LITERATURE MEASURES TO REDUCE RISKY AND HEAVY ALCOHOL DRINKING IN THE POPULATION OF STUDENTS: A SYSTEMATIC LITERATURE REVIEW
}

Irena Makivić ${ }^{1}$, Janko Kersnik ${ }^{1}$, Marko Kolšek ${ }^{1}$

Prispelo: 2. 8. 2011 - Sprejeto: 24. 9. 2012

Pregledni znanstveni članek UDK 613.81-053.6(497.4)

\section{Izvleček}

Izhodišča: Pitje alkohola je precej velik slovenski problem; še posebej so izpostavljeni mladi pivci. Pomembne so preventivne in intervencijske metode $v$ populaciji študentov, a $v$ Sloveniji to področje še ni dovolj razvito. Sistematični pregled literature ponuja vpogled $v$ raziskovanje tega problema drugod po svetu in osvetljuje to področje pri nas.

Metode: Iz treh različnih baz (PubMED, Cochrane in PsychINFO) smo s pomočjo ključnih besed (alcohol drinking/ consumption/abuse, prevention and control, students, intervention(s)) izbrali izvirne članke $v$ angleškem jeziku. Nanašali so se na mlade, stare od 18 do 25 let; obravnavali so vedenje glede pitja alkohola in vsebovali preventivne ali intervencijske dejavnosti.

Rezultati: Za prenos intervencij moramo poznati okolje, družbo in družbeni razvoj. Za učinkovite ukrepe so se pokazali: presejanje, kratki ukrepi ob ugotovljenem tveganem pitju (individualni in prek svetovnega spleta), motivacijski razgovori, spodbujanje mladih k idejam o nepitju alkohola, nadzor nad porabo alkohola znotraj študentskih naselij, povišanje cen alkoholnih pijač, omejitev oglaševanja in reorganizacija vplivov na spremembe vrednot, ki vplivajo na porabo alkohola.

Zaključki: Specifičnost mlade/študentske populacije predstavlja izziv in dobro naložbo za prihodnost.

Ključne besede: preventiva, nadzor, študentje, tvegano pitje, škodljivo pitje, kratki ukrepi

Review article

UDC 613.81-053.6(497.4)

\section{Abstract}

Background: Alcohol drinking is quite a large problem in Slovenia; young people are particularly exposed to hazardous and also harmful drinking. Prevention and intervention methods are most important in the student population, but in Slovenia this area is not yet sufficiently developed. A systematic literature review provides insight into the research of the problem worldwide and is highlighted in this area in Slovenia.

Methods: We selected original articles in the English language from three different databases (PubMED, Cochrane and PsychINFO) using keywords in English (alcohol drinking/consumption/abuse, prevention and control, students, intervention(s)). Articles relating to young adults aged 18 to 25 years, studying the behaviour with regard to drinking alcohol and including prevention or intervention activities.

Results: To be able to transfer various interventions into our environment, the expertise of milieu, society and social development must be know. Effective preventive actions are screening, brief individual or web based interventions, motivational interviews, promoting ideas about not drinking alcohol to young people, supervision over alcohol consumption in student areas, increase in prices of alcoholic beverages, advertisement restrictions according to alcohol and changing the values that affect levels of alcohol consumption.

Conclusions: The specificity of the young/student population is the challenge and a good investment for the future.

Key words: prevention, control, students, hazardous drinking, harmful drinking, brief interventions 


\section{UVOD}

Slovenija je med 51 evropskimi državami na tretjem mestu po porabi alkohola (1). Na visoko porabo alkohola kaže podatek iz leta 2007, ko je bila registrirana letna poraba na prebivalca 9,5 litra čistega alkohola oziroma 11 litrov na prebivalca, starega 15 let in več. Poleg registrirane porabe je tu še neregistrirana (letno od 5 do 7 litrov čistega alkohola na prebivalca, starega 15 let in več), ki Slovenijo še bolj utrdi visoko na lestvici držav z najvišjo porabo alkohola na prebivalca (2). Raziskava slovenskega javnega mnenja iz leta 1999 kaže, da je med odraslimi prebivalci le $5 \%$ ljudi, ki v življenju še nikoli niso popili niti kozarca alkoholne pijače (3), medtem ko je odstotek takšnih v poznejših raziskavah (SJM 2001) še celo padel (na $4 \%$ ) (4). Je pa kar 63,6 \% t.i. zmernih (pijejo na manj tvegan način) in 21,4\% čezmernih pivcev (ženske, ki popijejo več kot $10 \mathrm{~g}$, moški več kot $20 \mathrm{~g}$ čistega alkohola dnevno); izstopajo mladostniki, saj jih je v zadnjem letu pilo $87 \%$ (5). Zanimivo pa novejši podatki (2004) kažejo, da je odstotek čezmernih pivcev padel (13,4\%), medtem ko je odstotek ljudi, ki pijejo na manj tvegan način, narastel na 71,4 \% (6). Razloge, da tretjina odraslih moških in deset odstotkov odraslih žensk sodi v skupino tveganih pivcev, gre iskati tudi v slovenski kulturi, katere del je alkohol. Pitje alkohola in biti pijan je nekaj navadnega in sprejetega, medtem ko je nenavadno biti abstinent (7). Vsaj enkrat letno se opije $42,5 \%$ slovenskih anketirancev, kar predstavlja tudi oceno ogroženosti prebivalstva Slovenije za opijanje z alkoholnimi pijačami vsaj enkrat letno $(0,425)$. Pri tem je odstotek pogostosti opijanja največji med mladimi od 25. do 29. leta starosti (6).

$Z$ vidika javnega zdravja je preventivno obnašanje pomembno s stališča zdravstva - večji vložek v preventivo pomeni manjše potrebe po vložkih za zdravljenje -ter tudi s stališča posameznika (nasilje $v$ družini, socialne težave in kriminal) in zdrave družbe, saj alkohol povzroča tudi upad produktivnosti in povečanje odsotnosti $z$ delovnega mesta (7). Alkohol povečuje tveganje za vedenje, ki povzroča škodo $v$ družbi (zloraba, kriminal itn.) in posamezniku (zasvojenost in bolezni) (2). Velik odstotek prometnih nesreč povzročijo mladi vozniki, med katerimi so številni tudi pijani (7). Alkohol je v Evropi med mladimi od 15. do 29. leta prvi vzrok za prezgodnjo smrt (kar četrtina vseh smrti je povezana $z$ alkoholom) (2). Mlajša kot je oseba, ko začne piti alkohol, večje je tveganje za razvoj težav, povezanih z alkoholom, in za razvoj zasvojenosti z alkoholom pozneje $v$ življenju (2), zato je s stališča javnega zdravja promocija zdravega življenja brez alkohola ali s čim manj alkohola $v$ tem obdobju zelo pomembna (8).
Področje pitja alkohola med mladino in mladimi odraslimi v Sloveniji še ni dovolj raziskano, čeprav je nekaj obsežnejših študij že dalo zanimive izsledke (2, 9 - 12). Med drugim tudi, da z leti naraščata pitje alkohola in tudi spodbujanje k pitju alkohola (12). Podobno kažejo tudi izsledki raziskave ESPAD, da je povprečna količina popitega alkohola na zadnji dan, ko so pili, na nacionalni ravni narastla $v$ desetih državah, padla pa le v štirih (10). Dejstvo, da veliko študentov - kar ena tretjina - svoje težave in preobremenjenost (stres zaradi zahtevnega študija) rešuje $z$ občasnim pitjem alkohola in drugimi škodljivimi dejavnostmi (13), je skrb vzbujajoč podatek, še posebno, če gre za študente medicine, kljub pridobljenemu znanju o ohranjanju zdravja. Sicer pa tvegano pije alkohol $32 \%$ študentov, škodljivo pa $2 \%$. Večji je tudi odstotek študentov prvih letnikov v primerjavi z drugimi prebivalci Slovenije, ki pije tvegano, zato je področje preventivnega ukrepanja na tem mestu gotovo še kako pomembno (2).

Namen prispevka je sistematični pregled objavljenih člankov o ukrepih s področja preventive tveganega in škodljivega pitja študentske populacije pri nas in v tujini.

\section{METODE}

Narejena sta bila sistematični pregled literature o ukrepih za zmanjšanje tveganega in škodljivega pitja ter ocena izsledkov ukrepov. Članki so bili najprej razdeljeni po skupinah glede pomembnosti raziskav (preglednica 1). Merila, ki so bila nadalje uporabljena za rangiranje raziskav znotraj sklopov, so bila tri, in sicer 1. spremljanje učinkov ukrepov po določenem času, 2. dovolj velik vzorec ter 3. ustrezne statistike in ozki intervali zaupanja za randomizirane kontrolne raziskave. Za najmočnejše raziskave smo vzeli metaanalize, raziskave primerov $s$ kontrolami in $z$ longitudinalno raziskavo, sledijo presečne pregledne in druge raziskave. Na koncu pa so pregledni članki. Članke smo nadalje razdelili na tiste, katerih izsledki so imeli pozitiven (+) vpliv, negativen vpliv (-) ali pa oba (0). Pozitivni izsledki pomenijo vpliv ukrepov, negativni pa, da ukrep v raziskavi ni pokazal nobenega vpliva ali spremembe (Tabela 2).

\subsection{Vir podatkov}

Iskanje referenc je potekalo prek interneta po različnih bazah s pomočjo bulovih operatorjev za PubMED: »alcohol drinking « AND »prevention and control« AND »students «; za Cochrane: »alcohol consumption students interventions «; za PsycINFO: »alcohol abuse « AND »intervention « AND »students«. 


\subsection{Izbira raziskav}

Za izbiro ustreznih člankov so bila uporabljena stopenjska merila. Najdeni članek je bil ustrezen, če je vseboval raziskavo, povezano s preventivnimi programi ali $z$ drugimi ukrepi glede rabe alkohola pri mladih in/ ali študentih. Pri tem je treba dodati, da so preventivni programi namenjeni preprečevanju tveganega in škodljivega pitja, ukrepi pa so namenjeni tistim, ki že pijejo tvegano ali škodljivo. Izbira je bila na PubMedu zožena z vključitvijo člankov, če so bile izbrane ključne besede $v$ izvlečku ali naslovu članka, če so se nanašale na ljudi, če so bile v angleškem jeziku in če so bili članki objavljeni v zadnjih petih letih. Vseh ustreznih člankov glede na iskalni niz je bilo 315, od tega na PubMED 209, v Cochrane Library 10 in PsycINFO 96.

Ustreznost vključenih raziskav je bila ocenjena glede na primernost oziroma usklajenost $z$ iskalnim nizom. $V$ ožji izbor so vključene vse raziskave, ki se nanašajo na populacijo študentov oziroma mladih, starih od 18 do 25 let; zadevajo obnašanje glede pitja alkohola in vsebujejo kakršne koli preventivne ali druge intervencijske dejavnosti. Vključene so bile vse kvalitativne in kvantitativne raziskave različnih oblik. Niso pa bile vključene raziskave, ki so se dotikale še kakšnih drugih področij (npr. ukrepi na področju drog) ali niso vključevale populacije študentov. V končni izbor se je tako uvrstilo 23 člankov, ki so obravnavali ukrepe za zmanjšanje tveganega in škodljivega pitja pri študentski ali enako stari mladi populaciji.

Vse vključene raziskave smo prikazali tabelarično.

\section{REZULTATI}

Tabela 1 prikazuje, kakšen ukrep je potekal in kakšni so izsledki. Raziskave so razporejene glede na moč raziskave, pri čemer so upoštevane le originalne raziskave in metaanalize, zato o izseldkih preglednih člankov ne razpravljamo (33-36).

Tabela 1. Povzetek pregledanih raziskav.

Table 1. Summary of the research.

\begin{tabular}{|c|c|c|}
\hline $\begin{array}{c}\text { Vrsta raziskave (vir)/Type } \\
\text { of research (source) }\end{array}$ & Ukrep/Intervention & Izsledki/Results \\
\hline $\begin{array}{l}\text { Meta analiza/Meta-analysis } \\
\text { (14) }\end{array}$ & $\begin{array}{l}98 \text { različnih ukrepov/ } \\
\text { Different interventions. }\end{array}$ & $\begin{array}{l}\text { Tisti, ki so prejeli ukrepe (98 različnih ukrepov: } \\
\text { osebne ali prek računalnika, s tiskanimi navodili, } \\
\text { z motivacijskim intervjujem, izobraževanjem } \\
\text { itn.), so v večini pili manj in imeli manj težav, } \\
\text { povezanih z alkoholom. Največji vpliv so imeli } \\
\text { osebni ukrepi, ki so vsebovali neko povratno } \\
\text { informacijo in normativno primerjavo. Pomembni } \\
\text { pa so ukrepi, ki se osredinjajo na dolgotrajne } \\
\text { rezultate/učinke/Those who received the } \\
\text { interventions ( } 98 \text { different interventions: } \\
\text { personal or via a computer-printed instructions, } \\
\text { motivational interview, education, etc.) in most } \\
\text { drank less and have less problems associated } \\
\text { with alcohol. The biggest impact have had } \\
\text { personal intervention which contained some } \\
\text { sort of feedback and normative comparison. } \\
\text { The important ones are interventions that focus } \\
\text { on long-lasting results/effects. }\end{array}$ \\
\hline $\begin{array}{l}\text { Meta analiza/Meta-analysis } \\
\text { (15) }\end{array}$ & $\begin{array}{l}43 \text { računalniških ukrepov/ computer-based } \\
\text { interventions. }\end{array}$ & $\begin{array}{l}\text { Ukrepi prek računalnika zmanjšujejo količino } \\
\text { in pogostost pitja med študenti. Izkazali so se } \\
\text { za enakovredne drugim ukrepom/ Intervention } \\
\text { via computer reduce the amount and frequency } \\
\text { of drinking among college students. Those } \\
\text { interventions are equivalent to other alternative } \\
\text { interventions. }\end{array}$ \\
\hline
\end{tabular}




\begin{tabular}{|c|c|c|}
\hline $\begin{array}{l}\text { Vrsta raziskave (vir)/Type } \\
\text { of research (source) }\end{array}$ & Ukrep/Intervention & Izsledki/Results \\
\hline $\begin{array}{l}\text { Longitudinalna raziskava/ } \\
\text { Longitudinal survey } \\
\text { (16) }\end{array}$ & $\begin{array}{l}\text { 16-letna raziskava o porabi alkohola med } \\
\text { študenti, ki imajo ali nimajo zgodovine porabe } \\
\text { alkohola } v \text { družini/ } 16 \text {-annual survey on the } \\
\text { consumption of alcohol use among students } \\
\text { who have or do not have a history of alcohol } \\
\text { consumption in the family. }\end{array}$ & $\begin{array}{l}\text { Razlogi za pogostejšo abstinenco so povezani z } \\
\text { vzgojo in religijo; razlogi, temelječi na negativnih } \\
\text { izkušnjah, pa vplivajo bolj na povečanje porabe } \\
\text { alkohola med pivci/The reasons for increased } \\
\text { abstinence are associated with education } \\
\text { and religion; reasons based on negative } \\
\text { experiences influence the increase of alcohol } \\
\text { consumption in drinkers. }\end{array}$ \\
\hline $\begin{array}{l}\text { Randomizirana kontrolna } \\
\text { raziskava/ Randomised } \\
\text { controlled trial } \\
\text { (17) }\end{array}$ & $\begin{array}{l}\text { Spletni motivacijski test } z \text { individualiziranim } \\
\text { poročilom/ Online motivational test with } \\
\text { individualised report. }\end{array}$ & $\begin{array}{l}\text { Spletno presejanje in ukrep zmanjšujeta } \\
\text { pitje pri študentih/Web-based screening and } \\
\text { intervention reduce students' drinking. }\end{array}$ \\
\hline $\begin{array}{l}\text { Randomizirana kontrolna } \\
\text { raziskava/ Randomized } \\
\text { controlled trial } \\
\text { (18) }\end{array}$ & $\begin{array}{l}\text { Elektronsko (prek računalnika ali interneta) } \\
\text { presejanje in ukrep za tvegane pivce - spletni } \\
\text { ukrep, drugi dodatni ukrep po } 1 \text { in } 6 \text { mesecih/ } \\
\text { Electronically (via PC or Internet) screening } \\
\text { and intervention for risky drinkers. Web based } \\
\text { intervention, additional intervention after } 1 \text { and } \\
6 \text { months. }\end{array}$ & $\begin{array}{l}\text { Učinek ukrepa se ohrani } 12 \text { mesecev. Dodatni } \\
\text { ukrepi po } 1 \text { in/ali } 6 \text { mesecih nimajo dodatnega } \\
\text { učinka/Effect of intervention is maintained for } 12 \\
\text { months. Additional interventions after } 1 \text { and/or } \\
6 \text { months have no additional effect. }\end{array}$ \\
\hline $\begin{array}{l}\text { Randomizirana kontrolna } \\
\text { raziskava/ Randomized } \\
\text { controlled trial } \\
\text { (19) }\end{array}$ & $\begin{array}{l}\text { Ukrepi staršev, presejanje in ukrepi sovrstnikov } \\
\text { ali vse skupaj/Intervention by parents, screening } \\
\text { and intervention by peers or all together. }\end{array}$ & $\begin{array}{l}\text { Kombiniran vpliv treh ukrepov je pokazal nižjo } \\
\text { porabo alkohola, manj tveganega pitja in } \\
\text { pozitivne izide po } 10 \text { mesecih. Vpliv staršev na } \\
\text { otroke, preden odidejo od doma na fakulteto, } \\
\text { poveča učinkovitost presejanja in ukrepa/ } \\
\text { The Combined effect of three interventions } \\
\text { showed a lower consumption of alcohol, less } \\
\text { risky drinking and positive results after } 10 \\
\text { months. The influence of parents on children } \\
\text { before going from home to college increase } \\
\text { the effectiveness of screening and intervention. }\end{array}$ \\
\hline $\begin{array}{l}\text { Randomizirana kontrolna } \\
\text { raziskava/ Randomized } \\
\text { controlled trial } \\
\text { (20) }\end{array}$ & $\begin{array}{l}\text { Ukrep v obliki motivacijskega intervjuja in } \\
\text { usmerjen na zmanjšanje škodljivih učinkov/ } \\
\text { Intervention in the form of incentive interview } \\
\text { focused on reduction of adverse effects. }\end{array}$ & $\begin{array}{l}\text { Študentje, ki so prejeli ukrep v obliki } \\
\text { motivacijskega intervjuja, so še po } 24 \text { mesecih } \\
\text { pili manj alkohola ob eni priložnosti in imeli } \\
\text { manjše število točk pri vprašalnikih AUDIT } \\
\text { in RAPI/Students who have received an } \\
\text { intervention in the form of incentive interview } \\
\text { continue to drink less alcohol on one occasion } \\
\text { and have a smaller number of points in the } \\
\text { AUDIT and RAPI questionnaires, also after } \\
24 \text { months. }\end{array}$ \\
\hline $\begin{array}{l}\text { Randomizirana kontrolna } \\
\text { raziskava/ Randomized } \\
\text { controlled trial } \\
\text { (21) }\end{array}$ & $\begin{array}{l}\text { Trije ukrepi: motivacijski intervju v manjši } \\
\text { skupini, motivacijska predstava vrstnikov in } \\
\text { izobraževalni protialkoholni program/ Three } \\
\text { interventions: motivational interview in smaller } \\
\text { group, motivational peers' show and educational } \\
\text { anti-alcohol program. }\end{array}$ & $\begin{array}{l}\text { Niso se pokazali nobeni statistično značilni } \\
\text { vplivi treh ukrepov. Kratki ukrepi ne spremenijo } \\
\text { vedenja/Three interventions: motivational } \\
\text { interview in smaller group, motivational peers' } \\
\text { show and educational anti-alcohol program. }\end{array}$ \\
\hline
\end{tabular}




\begin{tabular}{|c|c|c|}
\hline $\begin{array}{l}\text { Vrsta raziskave (vir)/Type } \\
\text { of research (source) }\end{array}$ & Ukrep/Intervention & Izsledki/Results \\
\hline $\begin{array}{l}\text { Randomizirana kontrolna } \\
\text { raziskava/ Randomized } \\
\text { controlled trial } \\
\text { (22) }\end{array}$ & $\begin{array}{l}\text { Vpliv dveh kratkih motivacijskih ukrepov } \\
\text { (motivacijski intervjus strokovnjaki-zdravstveno } \\
\text { osebje v študentskem zdravstvenem domu)/ } \\
\text { Influence of two short incentive-based } \\
\text { interventions (motivational interview with } \\
\text { experts - medical staff in students' health care } \\
\text { centre). }\end{array}$ & $\begin{array}{l}\text { Motivacijski intervju vpliva na zmanjšanje } \\
\text { alkohola v krvi, zmanjšanje tveganega pitja in na } \\
\text { zmanjšanje škodljivega vedenja, povezanega z } \\
\text { alkoholom, pri ljudeh, ki so se na testu izkazali } \\
\text { za tvegane pivce/ Motivational interview affects } \\
\text { the reduction of alcohol in blood, reduces } \\
\text { the risk of drinking and reduces the harmful } \\
\text { behavior associated with alcohol in risky } \\
\text { drinking individuals. }\end{array}$ \\
\hline $\begin{array}{l}\text { Randomizirana kontrolna } \\
\text { raziskava/ Randomized } \\
\text { controlled trial } \\
\text { (23) }\end{array}$ & $\begin{array}{l}\text { Vpliv ocenjevanja o tveganem pitju na količino } \\
\text { popitega alkohola in zmanjšanje tveganega } \\
\text { vedenja, povezanega z alkoholom/Impact } \\
\text { of assessment of risky drinking alcohol } \\
\text { consumption and reduction of alcohol related } \\
\text { risk behavior. }\end{array}$ & $\begin{array}{l}\text { Za zmanjšanje tveganega vedenja, povezanega } \\
\text { zalkoholom, je učinkovitejše omejevanje porabe } \\
\text { alkohola kot pa samo pristop minimaliziranja } \\
\text { posledic popitega alkohola. Hkrati se je } \\
\text { pokazalo učinkoviteje (nižje vrednosti testa } \\
\text { AUDIT in pogostejša uporaba strategij za manj } \\
\text { tvegano pitje) ukrepati hitreje (vprašalnik po } 3 \text {, } \\
6 \text { in } 12 \text { mesecih) kot pa pozneje (vprašalnik } \\
\text { šele po } 12 \text { mesecih)/To reduce risk behavior } \\
\text { associated with alcohol, it is more efficient } \\
\text { to restrict the consumption of alcohol, rather } \\
\text { than just minimalization the consequences } \\
\text { of alcohol drinking. At the same time it was } \\
\text { proven that it is more efficient (lower AUDIT } \\
\text { test results and making more use of strategies } \\
\text { for less risky drinking) if we take an action } \\
\text { rapidly (questionnaire after } 3,6 \text { and } 12 \\
\text { months) in comparison to take the actions later } \\
\text { (questionnaire after } 12 \text { months). }\end{array}$ \\
\hline $\begin{array}{l}\text { Randomizirana kontrolna } \\
\text { raziskava/ Randomized } \\
\text { controlled trial } \\
\text { (24) }\end{array}$ & $\begin{array}{l}\text { Preverjati vpliv navodil za zmanjšanje } \\
\text { pitja alkohola ali povečanje preventivnega } \\
\text { obnašanja/Verifying the impact of counseling } \\
\text { for reducing alcohol consumption or increasing } \\
\text { their preventive behaviour. }\end{array}$ & $\begin{array}{l}\text { Tisti, ki so dobili navodila za zmanjšanje pitja, } \\
\text { so res zmanjšali pitje } v \text { primerjavi z drugo } \\
\text { (povečanje strategij) in kontrolno skupino. } \\
\text { Pomembno je, katero strategijo izberemo, ker } \\
\text { le povečanje uporabe strategij nadzora (da piješ } \\
\text { počasi ali ješ, preden piješ), brez zmanjšanja } \\
\text { pitja, ne pomeni vedno tudi zmanjšanja pitja/ } \\
\text { Those who are instructed to reduce drinking } \\
\text { are really reducing drinking in comparison with } \\
\text { other groups. It is important, what strategy is } \\
\text { chosen, since only the increase in use of control } \\
\text { strategies (to drink slowly or to eat before you } \\
\text { drink), without reducing drinking doesn't always } \\
\text { mean also real reduction of drinking. }\end{array}$ \\
\hline
\end{tabular}




\begin{tabular}{|c|c|c|}
\hline $\begin{array}{l}\text { Vrsta raziskave (vir)/Type } \\
\text { of research (source) }\end{array}$ & Ukrep/Intervention & Izsledki/Results \\
\hline $\begin{array}{l}\text { Randomizirana kontrolna } \\
\text { raziskava/ Randomized } \\
\text { controlled trial } \\
\text { (25) }\end{array}$ & $\begin{array}{l}\text { Izobraževanje, ki vključuje učinke alkohola, } \\
\text { bolezni in obnašanje, povezano z alkoholom } \\
\text { (video z nekdanjim alkoholikom)/ Education, } \\
\text { which includes the effects of alcohol, diseases } \\
\text { and behaviour related to alcohol (video with } \\
\text { former alcoholic). }\end{array}$ & $\begin{array}{l}\text { Izobraževanje o alkoholu - učinkih, } \\
\text { zdravstvenih problemih, povezanih s pitjem } \\
\text { in pivskim obnašanjem,ni imelo vpliva na pitje } \\
\text { oz. probleme zaradi pitja. Tak način lahko } \\
\text { poveča le zavedanje o zdravstvenih problemih, } \\
\text { povezanih s porabo alkohola, a manj učinkovito } \\
\text { spreminja pivske navade/ Education about } \\
\text { alcohol: effects, health problems associated } \\
\text { with drinking and drinking behaviour had no } \\
\text { impact on drinking. This way can only increase } \\
\text { the awareness of health problems related to the } \\
\text { consumption of alcohol but does less efficiently } \\
\text { change drinking habits. }\end{array}$ \\
\hline $\begin{array}{l}\text { Presečna pregledna } \\
\text { raziskava/Cross-sectional } \\
\text { study } \\
(26)\end{array}$ & $\begin{array}{l}\text { Vpliv spremembe (strožjih) zakonov glede } \\
\text { pitja alkohola na javnih univerzah/The impact } \\
\text { of changes (more stringent) laws regarding } \\
\text { drinking alcohol at public Universities. }\end{array}$ & $\begin{array}{l}\text { Strožji predpisi so povezani z zmanjšanjem } \\
\text { tveganega pitja. Pomemben element je } \\
\text { formaliziran nadzor, v tem primeru dekana/ } \\
\text { More stringent rules are associated with } \\
\text { reduction of risky drinking. An important } \\
\text { element is formalized control, in this case by } \\
\text { the Dean. }\end{array}$ \\
\hline $\begin{array}{l}\text { Presečna pregledna } \\
\text { raziskava/Cross-sectional } \\
\text { study } \\
(27)\end{array}$ & $\begin{array}{l}\text { Vpliv referenčnih skupin na posameznikovo } \\
\text { pitje - povezava med oceno pitja referenčnih } \\
\text { skupin (kaj je normativno sprejeto) in dejanskim } \\
\text { stanjem (koliko posameznik pije)/The impact of } \\
\text { the reference groups on the individual's drinking } \\
\text { - a link between the assessment about drinking } \\
\text { of this reference groups (what is normative } \\
\text { accepted) and the actual situation (how much } \\
\text { the person drinks). }\end{array}$ & $\begin{array}{l}\text { Za skupine, ki so bile podobne njihovim lastnim } \\
\text { osebnim značilnostim, so se ocenjene norme } \\
\text { pokazale enake kot posameznikovo pivsko } \\
\text { vedenje/For the groups, which are similar to } \\
\text { their personal characteristics, evaluated norms } \\
\text { shown to be the same as their drinking bahavior. }\end{array}$ \\
\hline $\begin{array}{l}\text { Presečna pregledna } \\
\text { raziskava/Cross-sectional } \\
\text { study } \\
(28)\end{array}$ & $\begin{array}{l}\text { Preverjali so sprejetost različnih postopanj } \\
\text { za prenehanje ali zmanjšanje pitja alkohola } \\
\text { (knjiga za samopomoč, računalniški program } \\
\text { za samopomoč, skupina za samopomoč, } \\
\text { skupinska terapija, individualna terapija, } \\
\text { mesečna injekcija zdravila, dnevna zdravila)/ } \\
\text { Checking the acceptance of different actions } \\
\text { for terminating or reducing alcohol drinking } \\
\text { (self-help book, self-help computer program, } \\
\text { self-help group, group therapy, individual } \\
\text { therapy, monthly injection medication, daily } \\
\text { medications). }\end{array}$ & $\begin{array}{l}\text { Več kot } 50 \% \text { tveganih pivcev bi (ob odločitvi } \\
\text { za zmanjšanje ali prenehanje pitja) izbralo } \\
\text { samopomoč ali psihoterapijo, več kot } 25 \% \\
\text { pa zdravila/More than } 50 \% \text { of risky drinkers } \\
\text { would (if they decide to reduce or stop drinking) } \\
\text { choose self-help or psychotherapy, more than } \\
25 \% \text { of them would choose a drugs option. }\end{array}$ \\
\hline
\end{tabular}




\begin{tabular}{|c|c|c|}
\hline $\begin{array}{l}\text { Vrsta raziskave (vir)/Type } \\
\text { of research (source) }\end{array}$ & Ukrep/Intervention & Izsledki/Results \\
\hline $\begin{array}{l}\text { Presečna pregledna } \\
\text { raziskava/Cross-sectional } \\
\text { study } \\
\text { (29) }\end{array}$ & $\begin{array}{l}\text { Pregled učinkov strategij za nadzor porabe } \\
\text { alkohola na pitje alkohola (izogibanje pivskim } \\
\text { igricam, pitje »na eks«, izogibanje popivanju, } \\
\text { uporaba strategij med pitjem ali nepitje)/An } \\
\text { overview of the effects of strategies to control } \\
\text { the consumption of alcohol on alcohol drinking } \\
\text { (avoiding drinking games, avoiding heavy } \\
\text { drinking, use of strategies during drinking or } \\
\text { not drinking). }\end{array}$ & $\begin{array}{l}\text { Izogibanje situacijam, ko bi lahko pili še več } \\
\text { (pivske igre in podobno) in nepitje sta negativno } \\
\text { povezana s porabo alkohola, medtem ko so } \\
\text { strategije, uporabljene med pitjem (namenjena } \\
\text { količina denarja za pijačo, počasno pitje itn.), } \\
\text { pozitivno povezane s pitjem. To pomeni, da je } \\
\text { pomembno, kakšna strategija je vključena v } \\
\text { ukrep -če za rezultat želimo prenehanje pitja, je } \\
\text { pomembna strategija izogibati se težkemu pitju } \\
\text { oziroma prenehanje pitja/Avoiding situations } \\
\text { where you could drink more (Brewers ' games } \\
\text { and simolar) and non drinking behaviour } \\
\text { are negatively associated with consumption } \\
\text { of alcohol. While the strategies used during } \\
\text { drinking (certain amount of money for drinks, } \\
\text { slow drinking, etc.) are positively associated } \\
\text { with drinking. This means that it is important, } \\
\text { what kind of strategy is incorporated into } \\
\text { intervention - if we want to stop drinking } \\
\text { important strategy is to avoid heavy drinking } \\
\text { or cessation of drinking. }\end{array}$ \\
\hline $\begin{array}{l}\text { Presečna pregledna } \\
\text { raziskava/Cross-sectional } \\
\text { study } \\
(30)\end{array}$ & $\begin{array}{l}\text { Pregledati odnos med uporabo zaščitnega } \\
\text { obnašanja, porabo alkohola in posledicami, } \\
\text { povezanimi z alkoholom/Examine the } \\
\text { relationship between the use of protective } \\
\text { behaviour, alcohol consumption and } \\
\text { consequences associated with alcohol. }\end{array}$ & $\begin{array}{l}\text { Samozadostnost, učinkovitost in subjektivne } \\
\text { norme so povezane s pogostostjo uporabe } \\
\text { zaščitnega obnašanja/Self-sufficiency, } \\
\text { efficiency and subjective norms are related to } \\
\text { the frequency of use of protective behaviour. }\end{array}$ \\
\hline $\begin{array}{c}\text { Razvoj determinističnega } \\
\text { primerjalnega modela pitja } \\
\text { alkohola/ Development of } \\
\text { deterministic comparative } \\
\text { alcohol drinking model } \\
\text { (31) }\end{array}$ & $\begin{array}{l}\text { Napoved vzorcev pitja glede na lastnosti } \\
\text { kampusa/ Predicting patterns depending on } \\
\text { characteristics of a campus. }\end{array}$ & $\begin{array}{l}\text { Preprost model je primerno napovedal dejanski } \\
\text { vzorec pitja glede na tip okolja - "mokroto “ } \\
\text { kampusov (število barov v bližini)/A simple } \\
\text { model is appropriate for predcisting of actual } \\
\text { pattern of drinking according to the type of the } \\
\text { environment - "wetness" of the Campus (the } \\
\text { number of bars in the surroundings). }\end{array}$ \\
\hline $\begin{array}{c}\text { Ekološka raziskava, } \\
\text { eksperiment: terenski } \\
\text { poskus/Experimental study } \\
\text { (32) }\end{array}$ & $\begin{array}{l}\text { Povečanje kontrole zabav in sodelovanje } \\
\text { z mestom za zmanjšanje ponavljajočih se } \\
\text { problematičnih zabav; ozaveščanje študentov } \\
\text { o varnem življenju in uvedba drugih programov/ } \\
\text { Increase parties control and cooperation with } \\
\text { the city for reducing the recurrent problematic } \\
\text { parties; increasing awareness of safe life and } \\
\text { introducing another programs. }\end{array}$ & $\begin{array}{l}\text { Prevalenca pitja je bila v kampusih, v katerih } \\
\text { so uporabili ukrep, statistično značilno manjša. } \\
\text { Večji nadzor nad porabo alkohola je učinkovit } \\
\text { pri zmanjšanju tveganega pitja/ Prevalence } \\
\text { of drinking in Campuses where they used the } \\
\text { intervention, was significantly smaller. More } \\
\text { control over consumption of alcohol is effective } \\
\text { in reducing risky drinking. }\end{array}$ \\
\hline $\begin{array}{c}\text { Pregledni članek/ } \\
\text { Systematic literature review } \\
\text { (33) }\end{array}$ & $\begin{array}{l}\text { Pregled učinkov ukrepov/ Overview of the } \\
\text { interventions' effects (2004-2005). }\end{array}$ & $x$ \\
\hline $\begin{array}{c}\text { Pregledni članek/ } \\
\text { Systematic literature review } \\
\text { (34) }\end{array}$ & $\begin{array}{l}\text { Pregled } 17 \text { spletnih ukrepov (od leta 2007)/ } \\
\text { Review of } 17 \mathrm{~s} \text { Web-based interventions (from } \\
\text { year 2007). }\end{array}$ & $x$ \\
\hline
\end{tabular}




\begin{tabular}{|c|l|l|}
\hline $\begin{array}{c}\text { Vrsta raziskave (vir)/Type } \\
\text { of research (source) }\end{array}$ & Ukrep/Intervention & Izsledki/Results \\
\hline $\begin{array}{c}\text { Pregledni članek/ } \\
\text { Systematic literature review } \\
(35)\end{array}$ & $\begin{array}{l}\text { Pregled ukrepov, usmerjenih na spremembo } \\
\text { znanja, okolja, varovanja zdravja in intervencijske } \\
\text { službe/An overview of interventions focused on } \\
\text { the change of knowledge, environment, health } \\
\text { and safety, and intervention services. }\end{array}$ & $x$ \\
\hline $\begin{array}{c}\text { Systematic literature review } \\
\text { (36) }\end{array}$ & $\begin{array}{l}\text { Pregled preventivnih in intervencijskih } \\
\text { programov, povezanih z dejavniki vpliva na pitje } \\
\text { študentov prvih letnikov na univerzi/An overview } \\
\text { of prevention and intervention programs related } \\
\text { to factors affecting first year university students' } \\
\text { drinking. }\end{array}$ & $x$ \\
\hline
\end{tabular}

V nadaljevanju (Tabela 2) so povzete ugotovitve 19 člankov (iz tabele izključeni pregledni članki (33-36)). Pokazalo se je, da je nekaj takšnih raziskav, kjer je bilo bodisi nemogoče določiti, kakšen je rezultat (oznaka 0 v Tabeli 2) ali pa sta $v$ zaključku tako pozitiven, kot negativen rezultat. Raziskav, ki so pokazale pozitivne rezultate ( $v$ Tabeli 2 označeno z znakom plus), je trinajst $(14,15,17,19,20,22-24,26,27,30-32)$, negativne rezultate ( $v$ tabeli 2 označeno $z$ znakom minus) sta pokazali le dve raziskavi $(21,25)$.

Tabela 2. ozitivnost oziroma negativnost izsledkov raziskav.

Table 2. The positivity or negativity of research results.

\begin{tabular}{|c|c|c|}
\hline Metaanaliza/Meta-analysis & + & 14,15 \\
\hline $\begin{array}{c}\text { Randomizirane kontrolne raziskave/ Randomized } \\
\text { controlled trial }\end{array}$ & + & $17,19,20,22,23,24$ \\
\cline { 2 - 3 } & 0 & 16,18 \\
\cline { 2 - 3 } & - & 21,25 \\
\hline Presečne pregledne raziskave/Cross-sectional study & + & $26,27,30$ \\
\cline { 2 - 3 } $\begin{array}{c}\text { Razvoj determinističnega primerjalnega modela/ } \\
\text { Development of deterministic comparative alcohol drinking } \\
\text { model }\end{array}$ & + & 28,29 \\
\hline Eksperiment: terenski poskus/Experimental study & + & 31 \\
\hline
\end{tabular}

\section{RAZPRAVA}

\subsection{Razprava o metodah, omejitvah in o prednostih pregleda}

Uporabljena je bila metoda sistematičnega pregleda literature z vnaprej določenimi iskalniki. PubMed PsychINFO in Cohrane so bili izbrani zaradi zdravstvenopsihološkega področja, ki ga iskalniki zajemajo, Cohrane ponuja številne kakovostne pregledne vire, skupaj pa ponujajo celovit zajem virov. Omejitev predstavlja dejstvo, da so bili vključeni le spletno dostopni članki v angleščini. Nadaljnji pregled v tej smeri bi lahko vključil tudi spletno nedostopne članke (npr. prispevki na konferencah, diplomske in magistrske naloge, doktorati itn.) in članke v drugih jezikih. Prednost tega pregleda je, da je to eden prvih poskusov sistematičnega pregleda ukrepov za preprečevanje tveganega in škodljivega pitja alkohola pri študentih. 


\subsection{Razprava o ugotovitvah}

\section{Povzetek razprave}

Raziskave so pokazale, da so na področju preventive pri mladih učinkoviti različni ukrepi. Osebni ukrepi, ki vsebujejo neko povratno informacijo, so se izkazali za učinkovitejše kot neosebni (14). Pomembno je vedeti, kateri dogodki so pri mladih tako pomembni, da bi s spremembo pristopa do teh dogodkov (spodbujanje neuporabe alkohola) dosegli velik rezultat (na primer polnoletnost, vstop na fakulteto, diploma itn.). Pri vsem pa se je pomembno osrediniti tudi na starše, ker imajo ukrepi s pomočjo (predhodnega) vpliva staršev še večji učinek (19). Preprečevanja tveganega pitja pri mladih se je treba lotiti že z izobraževanjem o spodbujanju zdravega načina življenja staršev ter nadaljevati z otroki in mladostniki. Na spremembo pivskih navad lahko vpliva tudi (osebni) zdravnik (22). Hkrati pa je pomembno, da učinke morebitnih novih ukrepov preverjajo po določenem času, saj je pomemben ravno dolgotrajnejši učinek.

Smiselno bi bilo povišati cene alkoholnih pijač, da bi s tem vsaj na neki način omejili dostop do alkohola in tako zmanjšali njegove škodljive posledice $(37,38)$. Projekt Sporočilo $v$ steklenici in spletno stran tega projekta (www.nalijem.si) bi bilo treba še bolj popularizirati med mladimi, saj so se tudi z raziskavami spletno presejanje in ukrepi izkazali za učinkovite $(15,17)$. Uporaba spletnih medijev narašča, postajajo vedno bolj osebni in vpliv je posledično (lahko) večji. Raziskave so še pokazale, da bi ob prenehanju pitja mladi najraje izbrali samopomoč v obliki knjige, računalniškega programa ali skupine (28). Spletno dosegljive zloženke/knjige in socialna spletna omrežja so ključnega pomena; tako bi lahko na ta način (pozitivno) vplivali na mlade pri rabi alkohola. Forum, na katerem bi mladi lahko med mladimi širili preventivne ideje proti tvegani in škodljivi rabi alkohola, bi lahko problem pitja spreminjal pri koreninah - pri normativnih okvirih, kaj mladi mislijo, da je normalno, pričakovano in splošno sprejeto - tako kot se je npr. pokazal vpliv referenčnih skupin (27). Glede takšnega ukrepa bi se lahko obrnili na mladinske in študentske organizacije ter njihove aktiviste. Ne nazadnje bi bilo mogoče smiselno tudi spodbujanje strožjega nadzora v študentskih naseljih glede porabe alkohola - prek nadzornikov (sovrstnikov, dekana, drugih uradnih oseb) ali omejevanja dostopa do barov - manjše število barov ali težji dostop do alkohola (omejitev mladoletnim, vinjenim ali višje cene), saj so se izkazali za učinkovite ukrepe $(26,31,32,37,38)$. Pri vsem pa ne gre pozabiti, da kljub velikemu družbenemu vplivu veliko težo nosi tudi osebnost posameznika (30).

\section{Vloga staršev in osebnih norm}

Vpliv staršev na omejevanje pitja je pomemben (16, 19) predvsem $v$ obdobju pred odhodom mladih od doma (19), o njihovi vlogi pozneje pa ni razpoložljivih podatkov. Negativne izkušnje $v$ družini lahko vplivajo na večjo uporabo alkohola (16). Pomembno zaščitno vlogo imajo osebne pozitivne norme mladih (30). Tudi vzgoja in religija sta lahko razlog za abstinenco (16).

\section{Ukrepi}

Različni ukrepi pri mladih so se izkazali za uspešne. Ti so lahko administrativni, individualni, v tiskani obliki ali celo prek interneta. Učinkoviti so različni administrativni ukrepi, ki omejujejo dostop in rabo alkohola $(23,26,32)$. Najučinkovitejši so sicer osebni ukrepi za zmanjšanje tveganega pitja (22), še zlasti, če vključujejo individualne povratne informacije (14). Te so pomembne tudi zato, ker se ocena količine popitega referenčnih skupin ujema z lastnim pitjem (27). Ti ukrepi so se izkazali za enakovredne preostalim ukrepom $(15,17)$, kar daje podporo tudi spletnemu svetovanju, kot je v Sloveniji npr. prek spletne strani www.nalijem. si (39). Pomembna je izbira strategije, saj na primer le povečanje preventivnih strategij (počasno pitje, uživanje hrane pred pitjem) ne prispeva k zmanjšanju pitja $(24,29)$.

Nekateri kratki ukrepi, na primer motivacijski intervju v majhni skupini, gledališke predstave kolegov in alkoholni izobraževalni programi za tvegane pivce, se niso izkazali za uspešne pri spremembi vedenja $(21,25)$, čeprav se poveča zavedanje o zdravstvenih problemih, povezanih z rabo alkohola.

\section{Trajanje učinka ukrepov}

Ukrepi imajo poleg kratkotrajnega učinka učinek tudi po več mesecih (17-20, 23, 25), medtem ko se ponavljanje intervencij ni pokazalo za učinkovitejše (18). Pomembno pa je ukrepanje dovolj zgodaj (23).

\subsection{Mogoče raziskave v Sloveniji}

Raziskava DeJonga in drugih (33) je pokazala, da so ukrepi, temelječi na dokazih, učinkovitejši, kar pomeni, da je raziskovanje, preverjanje in iskanje primernih ukrepov pomembno.

Ni pomembno le obstajanje zakonov, ampak tudi dosledno izvajanje predpisov o omejitvah pri prodaji alkohola in (u)porabi alkohola (Španija na primer ne dovoljuje pitja alkohola na javnih prostorih). Za začetek bi lahko preverili, ali obstajajo razlike, v katerih barih študenti popijejo več glede na dosledno upoštevanje zakona (prepovedana prodaja alkohola mladoletnim in vinjenim osebam). Učinkovitost zgoraj pokazanih raziskav bi v slovenskem modelu preverjali 
v študentskih domovih - ali pijejo več tisti študentje, ki živijo v študentskih domovih, ali tisti, ki živijo pri zasebnikih. Lahko bi izvedli raziskavo, v kateri bi preverjali vpliv staršev na mladostniško pitje. Lahko bi preverili vpliv širše kampanje, ki bi povsem prepovedala oglaševanje alkohola, spodbudila oglaševanje proti alkoholu - njegovih negativnih učinkih in posledic - ter prek mladih vrstnikom širila informacije, kako zmanjšati ali opustiti tvegano pitje alkohola. Sicer pa v Sloveniji že od leta 2003 teče projekt "Sporočilo iz steklenice«, katerega namen je spremeniti odnos do alkohola in zmanjšati škodljive posledice, ki jih alkohol povzroča posredno ali neposredno (40). Raziskava s strokovnjaki z različnih področij je pokazala, da je pomembno organizirati izobraževalne programe za mlade, ki zadevajo posledice tveganega pitja, in sicer z željo po zavedanju teh posledic in spremembi življenjskega sloga (7).

\section{ZAKLJUČEK}

Mladi so specifična populacija, za katero bi lahko rekli, da ne misli veliko na prihodnost in starostne probleme, kot so bolezni in nesreče. Zato je pomembno, da ostajamo tudi pri preventivnih akcijah v sedanjosti. To pomeni, da začnemo določene ukrepe na ravni družbe, nadaljujemo pa na ravni posameznikov. Z ukrepi, ki se dotikajo posameznikov danes, posledic, ki jih doletijo jutri, in individualnim pristopom bi lahko dosegli veliko. Med ukrepi se je sledenje po določenem času izkazalo za pomemben faktor. Tako se lahko dobro oceni učinek ukrepa, saj je dolgotrajen učinek pri pitju alkohola ključnega pomena, mogoče celo bolj kot pri kakšni drugi problematiki. Pomembnejše kot trenutno prenehanje oz. zmanjšanje pitja je dolgotrajna sprememba pivskih navad, preferenc in norm. Za namen ugotavljanja dolgotrajnega vpliva ukrepov na spremembo pivskih navad pa je treba spremembe opazovati tudi po več kot 12 mesecih.

\section{Literatura}

1. Poplas Susič T, Kersnik J, Kolšek M. Why do general practitioners not screen and intervene regarding alcohol consumption in Slovenia? A focus group study. Wien Klin Wochenschr 2010; Suppl 2: 1-5.

2. Rebek K. Pivske navade študentov Univerze v Ljubljani: raziskovalna naloga za Prešernovo nagrado. Ljubljana: Univerza v Ljubljani, 2010.

3. Toš N, Grizold A, Malnar B, Hafner-Fink M, Štebe J, Uhan S, et al. Slovensko javno mnenje 1999/2: stališča o zdravju in zdravstvu III in Mednarodna raziskava o kakovosti življenja. Ljubljana: Univerza v Ljubljani, Fakulteta za družbene vede, Center za raziskovanje javnega mnenja in množičnih komunikacij, 1999.
4. Toš N, Malnar B, Hafner-Fink M, Štebe J, Uhan S, Kurdija S, et al. Slovensko javno mnenje 2001/3: raziskava o zdravju in zdravstvu IV. in Raziskava o obrambi in varnosti. Ljubljana: Univerza v Ljubljani, Fakulteta za družbene vede, Center za raziskovanje javnega mnenja in množičnih komunikacij, 2001.

5. Inštitut za varovanje zdravja Republike Slovenije. Epidemiološke raziskave o pivskem vedenju v Sloveniji. Pridobljeno 23.4.2011 s spletne strani: http://ivz.si/ Mp.aspx?ni=78\&pi=6\&_6_id=565\&_6_Pagelndex=0\&_6_ groupld=2\&_6_newsCategory=IVZ+kategorija\&_6_ action=ShowNewsFull\&pl=78-6.0

6. Zaletel-Kragelj L, Fras Z, Maučec-Zakotnik J. Tvegana vedenja, povezana z zdravjem in nekatera zdravstvena stanja pri odraslih prebivalcih Slovenije: rezultati raziskave Dejavniki tveganja za nenalezljive bolezni pri odraslih prebivalcih Slovenije (z zdravjem povezan vedenjski slog). Ljubljana: CINDI Slovenija, 2004.

7. Poplas Susič T, Švab I, Kolšek M. Community actions against alcohol drinking in Slovenia: a Delphy study. Drug Alcohol Depend 2006; 83: 255-261.

8. Kolšek M, Struzzo P, Švab I. Qualitative study on community and primary health care involvement on alcohol and tobacco actions in seven European countries. Informa Healthcare 2008; 43: 303-316.

9. Kolšek M. Pogostost pitja alkohola in pivske navade osnovnošolcev v Sloveniji: doktorska naloga. Ljubljana: Univerza v Ljubljani, 2000.

10. Espad. Pridobljeno 25.5.2010 s spletne strani: http://www.espad. org/

11. Čebašek-Travnik Z, Sorko N, Boben D, Zorko M, Levačič M. Pot v odraslost: $z$ ali brez alkohola. Publikacija društva Žarek upanja. Pridobljeno 6.6.2011 s spletne strani: http://www.zarekupanja. net/files/raziskovalna_dejavnost/odraslost_z_ali_brez_alkohola_ prezentacija.pdf

12. Študentska organizacija univerze v Ljubljani. Ali je tudi $0,5 \%$ preveč? Zbornik simpozija o vožnji pod vplivom alkohola.

13. Krokter-Kogoj T. Ocena lastnega zdravja študentov Medicinske fakultete Univerze v Ljubljani: raziskovalna naloga za Prešernovo nagrado. Ljubljana: Medicinska fakulteta, 2008.

14. Carey KB, Scott-Sheldon LA, Carey MP, DeMartini KS. Individuallevel Interventions to reduce college student drinking: a metaanalytical review. Addict Behav 2007; 32: 2469-2494.

15. Carey KB, Scott-Sheldon LA, Elliott JC, Bolles JR, Carey MP. Computer -delivered interventions to reduce college student drinking: a meta-analysis. Addiction 2009; 104: 1807-1819.

16. Epler AJ, Sher KJ, Piasecki TM. Reasons for abstaining or limiting drinking: a developmental perspective. Psychol Addict Behav 2009; 23: 428-442.

17. Kypri K, Hallett J, Howat P, McManus A, Maycock B, Bowe S et al. Randomized controlled trial of proactive web based alcohol screening and brief intervention for university students. Arch Intern Med 2009; 169: 1508-1514.

18. Kypri K, Langley JD, Saunders JB, Cashell-Smith ML, Herbison $P$. Randomized controlled trial of web-based alcohol screening and brief intervention in primary care. Arch Intern Med 2008; 168: 530-536.

19. Turrisi R, Larimer ME, Mallett KA, Kilmer JR, Ray AE, Mastroleo $\mathrm{NR}$ et al. A randomized clinical trial evaluating a combined alcohol intervention for high-risk college students. J Stud Alcohol Drugs 2009; 70: 555-567.

20. Simao OM, Kerr-Correa F, Smaira SI, Trinca LA, Floripes TM, Dalben I et al. Epidemiology and prevention: prevention of »risky « drinking among students at a Brazilian University. Alcohol Alcohol 2008; 43: 470-476.

21. Cimini MD, Martens MP, Larimer ME, Kilmer JR, Neighbors C, Monserrati JM. Assessing the effectiveness of peer-facilitated 
interventions addressing high-risk drinking among judicially mandated coleege students. J Stud Alcohol Drugs 2009; Suppl 16: $57-66$

22. Schaus FJ, Sole ML, McCoy TP, Mullett N, O`Brien MC. Alcohol screening and brief intervention in a college student health center: a randomized controlled trial. J Stud Alcohol Drugs 2009; Suppl 16: 121-141.

23. Walters ST, Vader AM, Harris TR, Jouriles EN. Reactivity to alcohol assessment measures: an experimental test. Addiction 2009; 104: 1305-1310.

24. Sugarman DE, Carey KB. Drink less or drink slower: the effects of instruction in alcohol consumption and drinking control strategy use. Psychol Addict Behav 2009; 23: 577-585.

25. Geshi M, Hirokawa K, Taniguchi T, Fujii Y, Kawakami N. Effects of alcohol- related health education on alcohol and drinking behavior awareness among Japanese junior college students: a randomized controlled trial. Acta Med Okayama 2007; 61: 345354.

26. Harris SK, Sherritt L, Van Hook S, Wechsler H, Knight JR. Alcohol policy enforcement and changes in student drinking rates in a statewide public college system: a follow up study. Substance Abuse Treatment, Prevention and Policy 2010; 5: 18.

27. Larimer ME, Kaysen DL, Lee CM, Kilmer JR, Lewis MA, Dillworth $T$ et al. Evaluating level of specificity of normative referents in relation to personal drinking behavior. J Stud Alcohol Drugs 2009; Suppl 16: 115-121.

28. Epler AJ, Sher KJ, Loomis TB, O’Malley SS. College student receptiveness to various alcohol treatment options. J Am Coll Health 2009; 58: 26-32.

29. Sugarman DE, Carey KB. The relationship between drinking control strategies and college student alcohol use. Psychol Addict Behav 2007; 21: 338-345.

30. Ray AE, Turrisi R, Abar B, Peters KE. Social-cognitive correlates of protective drinking behaviors and alcohol-related consequences in college students. Addict Behav 2009; 34: 911917.
31. Scribner R, Ackleh AS, Fitzpatrick BG, Jacquez G, Thibodeaux JJ, Rommel R et al. A systems approach to college drinking: development of a deterministic model for testing alcohol control policies. J Stud Alcohol Drugs 2009; 79: 805-821.

32. Saltz RF, Welker LR, Paschall MJ, Feeney MA, Fabiano PM. Evaluating a comprehensive campus-community prevention intervention to reduce alcohol-related problems in a college population. J Stud Alcohol Drugs 2009; Suppl 16: 21-27.

33. DeJong W, Larimer ME, Wood MD, Hartman R. NIAAA`s rapid response to college drinking problems Initiative: reinforcing the use of evidence based approaches in college alcohol prevention. J Stud Alcohol Drugs 2009; Suppl 16: 5-11.

34. Elliot JC, Carey KB, Bolles JR. Computer-based interventions for college drinking: a qualitative review. Addict Behav 2008; 33 : 994-1005.

35. Neighbours C, Walters ST, Lee CM, Vader AM, Vehige T, Szigethy $T$ et al. Event-specific prevention: addressing college student drinking during known windows of risk. Addict Behav 2007; 32: 2667-2680.

36. Borsari B, Murphy JG, Barnett NP. Predictors of alcohol use during the first year of college: implications for prevention. Addict Behav 2007; 32: 2062-2086.

37. Wagenaar AC, Tobler AL, Komro KA. Effects of alcohol tax and price policies on morbidity and mortality: a systematic review. Am J Public Health 2010; 100: 2270-2278.

38. Osterberg EL. Alcohol tax changes and the use of alcohol in Europe. Drug Alcohol Rev 2011; 30: 124-129.

39. Sporočilo v steklenici. Pridobljeno 22.4.2011 s spletne strani: www.nalijem.si

40. Kolšek M. A long term preventive project on alcohol drinking in Slovenia. Drugs Educ Prev Policy 2007; 14: 173-180. 